\title{
The Dynamic Growth and Standing Stock of Acacia Decurrens Following the 2006 Eruption in Gunung Merapi National Park, Java, Indonesia
}

\author{
Priyono Suryanto \\ Faculty of Forestry, Gadjah Mada University, Yogyakarta, Indonesia \\ Faculty of Forestry, Universiti Putra Malaysia, Selangor, Malaysia \\ E-mail: psuryanto@ugm.ac.id \\ Mohd.Zaki Hamzah (Corresponding author) \\ Faculty of Forestry, Universiti Putra Malaysia \\ 43400 UPM SERDANG, Selangor, Malaysia \\ Tel: 60-133-911-872Ｅ-mail: zakihamzah@ymail.com \\ Azmy Mohamed \\ Faculty of Forestry, Universiti Putra Malaysia, Selangor, Malaysia \\ E-mail: Azmy5868@putra.upm.edu.my \\ Mohamad Azani Alias \\ Faculty of Forestry, Universiti Putra Malaysia, Selangor, Malaysia \\ E-mail: azani@putra.upm.edu.my
}

\begin{abstract}
Following the 2006 eruption in Mount Merapi, Indonesia, it is important to assess the dynamic growth and potential standing stock of Acacia decurrens as a woodfuel for the local community surrounding in the southern of Gunung Merapi National Park. Five plots (P1, P2, P3, P4 and P5), were established. This study carried out in May 2008. During the period of 18 months, we monitored the recruitment, mortality and survival of A.decurrens in the selected area. The performance of A.decurrens was examined, particularly its diameter, height, density, basal area, volume and relative rate change. The highest average diameter and height of A.decurrens were $14.22 \pm 1.85 \mathrm{~cm}$ and $5.97 \pm 0.66 \mathrm{~m}$, respectively. Standing stock was based on the highest average of the basal area (i.e. $72.07 \pm 18.51 \mathrm{~m}^{2} / \mathrm{ha}$ ) and volume (i.e. $184.44 \pm 24.59 \mathrm{~m}^{3} / \mathrm{ha}$ ). The results of this study were important information in supporting the Merapi lava tour and the standing stock of $A$. decurrens, which promises the local community with a schematic compatible management for GMNP.
\end{abstract}

Keywords: Succession, Dynamic growth, Standing stock, Acacia decurrens

\section{Introduction}

Mount Merapi is a place well-known for its 'firing mountain', which is among the identified 129 most active volcanoes found in Java (Dove, 2008). It is a stratovolcano and also one of the most active volcanic mountains in the world (Lavigne et al., 2000). The last major eruption of Mount Merapi in 2006, the mount erupted three times during the period between the months of May and June. While the lava from the May 2006 eruption flowed directly to Krasak and the Bedok River, the lava from the June eruption directed to the Gendol River. The eruption consisted of gaseous clouds that rapidly travelled $7 \mathrm{~km}$ down the southern slope of Merapi following the Gendol River (Charbonnier and Gertisser, 2008) and disturbing the Merkusii's pine forest stand, the Kaliadem Recreation Park and the private land of Kaliadem village. The gas formed by pyroclastic flow consisted of revolving superheated clouds called wedhus gembel in Javanese (nuée ardente in the international literature) or awan panas in Indonesian language (Dove, 2008). 
Acacia decurrens is a dominant species in the early succession of Mount Merapi (Suryanto et al., 2010). The characteristic of $A$. decurrens, i.e. a fast growing species, is a pioneer in the scarification of fire needed for its high adaptation to high temperature for germination (McDonald et al., 2002). It is a potential species for woodfuel (i.e. charcoal and firewood) for the local community living in the southern of Mount Merapi. For the community, fuel wood is the main source for residential cooking due to its low driven cost (Hadikusumah et al., 1991).

Gunung Merapi National Park (GMNP), located in Central Java Province and a special region of Yogyakarta since 2004, is Mount Merapi's famous national park (Ministry of Forestry, Indonesia, 2004). Thus, the assessment of dynamic and performance of $A$. decurrens can support GMNP as a sustainable and prospective national park. Generally, the natural disturbance of regime is referred to as the best model for managing forests (Seymour et al., 2002) and for vegetation features to be useful indicators of sustainable forest management that must be identified (Robets, 2007). Hence, the objectives of this study were to describe the early pattern dynamic of $A$. decurrens and its potential standing stock for the local community as woodfuel supply.

\section{Materials \& Methods}

\subsection{Study Site}

The study was conducted at Southern GMNP, which is situated in the Sleman district, Yogyakarta, Indonesia. GMNP which covers an area of about 6.410 ha, is located on elevation ranging from 600 to $2967 \mathrm{~m}$ asl. The climate of the area is categorized as wet tropic with the climate of C with Q 33.3-66\% based on Schmidt and Fergusson classification. The annual rainfall of about $875 \mathrm{~mm} \mathrm{year}^{-1}$ to about $2527 \mathrm{~mm} \mathrm{year}^{-1}$, with the wet months of November to May, and the dry month of June to October (Ministry of Forestry, Indonesia, 2004).

\subsection{Permanent Sample Plot}

We established 5 phytosociological relevés or permanent sample plot (labelled P1, P2, P3, P4 and P5), each with the size of $50 \times 20 \mathrm{~m}$ were established on two distinct locations, i.e., P1 (at elevation of $1210 \mathrm{~m}$ above sea level) and P2 $(1220 \mathrm{~m})$ were placed on the west bank of Gendol River, whereas P3 $(1250 \mathrm{~m})$, P4 $(1260 \mathrm{~m})$ and P5 $(1300 \mathrm{~m})$ were placed on the east bank of the river. Each plot was divided into 25 quadrates (each the size of $2 \mathrm{x}$ $2 \mathrm{~m}$ ). At the beginning of the study all of the tree were recorded, tagged and identified (census 1= May 2008). In addition, total height, diameter at breast height (DBH) and distribution of individual tree in each quadrate were also recorded. After six months, a census 2 (November 2008) and continued census 3 (May 2009) were conducted to record mortality (M) and recruitment (R). Approximately 18 months (census $4=$ November 2009) after census 1 , including the recording of all dead trees, recruitment, height and diameter.

\subsection{Analysis}

Within in the study plot, all data collected and analyzed with descriptive quantitative approach. During the period of 18 months, we monitored performance of A.decurrens was examined, particularly its diameter, height, basal area, volume and relative rate change with $\mathrm{dbh} \geq 1.5 \mathrm{~cm}$.

Basal area per plot calculated by:

BA per plot $=\sum_{i=1}^{n} \frac{1}{4} \pi d b h_{i}^{2}$

Volume per plot calculated by:

Volume per plot $=\sum_{i=1}^{n} \frac{1}{4} \pi d b h_{i}^{2} h_{i} 0.8$

Conversion from plot to per ha done by divided with plot size (ha). Relative rate change (RRC) is a relative change value from first census (Breugel et al., 2006). RRC in this study i.e height, diameter and basal area. RRC of each structural variable $X i$ was calculated over the two study years as the difference between the variable in the last $(X f)$ and the first census $(X i)$ as a proportion of $X i$ and corrected for the actual census period in days $(t)$.

$$
R R C_{(X)}=\left(\frac{x_{f}}{x_{i}}\right)^{\frac{365}{t}}-1
$$

Functional relationship analysis among parameters done by regression analysis. The best equation model done by curve fit estimation on SPSS. The equation used to describe relationship among parameters is a model with the highest R-square and the lowest of Mean Square Error (MSE). Special for calculated alpha ( $\alpha$ ), slope density, 
based on functional of diameter with model $\log \mathrm{N}=\log \beta-\alpha \log \mathrm{D}$ (Niklas et al., 2003).

\section{Results}

\subsection{Performance Growth of A. decurrens}

Based on the species that were established in the early succession of Mount Merapi, A. decurrens had a high adaptation and fast growth (i.e. diameter and height) which was better than the other species. Within all the plots, $\mathrm{P} 5$ had the lowest density of $A$. decurrens. Therefore the performance of $A$. decurrens focused on P1, P2, P3 and P4. Apparently, the performance of $A$. decurrens was similar in $\mathrm{P} 1, \mathrm{P} 2, \mathrm{P} 3$ and $\mathrm{P} 4$. The diameter growth of $A$. decurrens significantly increased in P4 - i.e. until $14.22 \pm 1.85 \mathrm{~cm}$ with a height of $5.97 \pm 0.66 \mathrm{~m}$. Meanwhile, the lowest diameter and height were found in P2, i.e. $4.85 \pm 0.63 \mathrm{~cm}$ and $3.03 \pm 0.56 \mathrm{~m}$, respectively. Based on density, the average of the highest density in P1 was $23965.22 \pm 4553.39$ individuals/ha, while the lowest was found in P2, which was $330.44 \pm 69.31$ individuals/ha (Table 1).

The RRC diameter and height in P4 were the highest compared with other plots, that were $111.05 \pm 13.33 \%$ and $131.89 \pm 17.80 \%$, respectively. $\mathrm{P} 2$ had the lowest RRC diameter and height, i.e. $38.60 \pm 6.56 \%$ and $42.45 \pm 8.49 \%$, respectively. Nevertheless, P2 had the highest RRC density, i.e. $58.10 \pm 12.20 \%$. In addition, the highest RRC recruitment was revealed in P1 (i.e. $3338.06 \pm 500.71 \%$ ), while the RRC mortality was $11566.73 \pm 1850.67 \%$ with the RRC survival of $50671.10 \pm 6587.24 \%$. The RRC recruitment, mortality and survival in P4 were the lowest, i.e. $334.19 \pm 56.81 \%, 455.01 \pm 59.15$ and $2747.12 \pm 302.18$, respectively (Table 2).

\subsection{Standing Stock of A. decurrens}

The standing stock of $A$. decurrens based on the basal area showed that P1 had the highest basal area, i.e. $72.07 \pm 18.51 \mathrm{~m}^{2} / \mathrm{h}$, while the lowest was found in P2, i.e. $0.45 \pm 0.08 \mathrm{~m}^{2} /$ ha. Based on volume, P4 had the highest, i.e. $184.44 \pm 24.59 \mathrm{~m}^{3} / \mathrm{ha}$, while the lowest was found in P2, i.e. $1.11 \pm 0.18 \mathrm{~m}^{3} / \mathrm{ha}$ (Figure 1). However, it was a different trend in the RRC basal area and volume of P4, which were the highest, i.e. $248.41 \pm 35.19 \%$ and $596.80 \pm 83.52 \%$, respectively. The lowest RRC basal area and volume were found in P2, i.e. $72.97 \pm 14.11 \%$ and $185.44 \pm 35.82 \%$, respectively (Table 2 ).

Based on the SPSS regression, the relationships among the initial basal area, diameter, height and basal area (RRC D, RRC H and RRC BA, respectively) were directly proportional, which followed the power model. The findings revealed that $R R C D$ had $R^{2}=0.781 \mathrm{p}$-value $=0.014$, while $R R C$ height had $\mathrm{R}^{2}=0.533 \mathrm{p}$-value $=0.041$. Conversely, the $R R C$ basal area had $R^{2}=0.795$-value $=0$. 008. Meanwhile, the relationship between the initial basal area and coefficient slope of density-diameter $(\alpha)$ was directly proportional, which followed the linear model, giving $\mathrm{R}^{2}=0.886 \mathrm{p}$-value $=0.004$ (Figure 2).

\section{Discussion}

The diameter and height trend growth of $A$. decurrens of the three-year post eruption had similarity with the dynamic species found in $\mathrm{P} 4$, which was the highest, while $\mathrm{P} 2$ had the lowest. The condition was also followed by the volume trend, but it was different with the basal area, i.e. P1 was the highest, while P4 was the lowest. Nonetheless, the RRC basal area and volume in P4 were the highest, whereas P2 had the lowest. Changing tree communities basal area in early succession stage are driven, in absolute and relative scales, by tree growth more than mortality and recruitment (Breugel et al., 2007).

Based on density, the average tree density of $A$. decurrens in $\mathrm{P} 1$ was the highest, while $\mathrm{P} 2$ had the lowest. On the other hand, P2 had the highest of RRC density, while P4 had the lowest. The density in the successional changes might indicate the potential for density, both in trees and the regenerating seedlings and saplings, depending on the effects of mortality, growth and recruitment (Uriarte et al., 2004). The relationship between the diameter and growth of $A$. decurrens was inversely proportionate, and had higher density of the lower level growth. Needless to say, the tree density is often negatively linked with the mean tree size (Condit el al., 1994). Nevertheless, in this study, this was different with the basal area, whereby the density was higher. Similar patterns had also been found elsewhere, revealing that the stand-level growth, mortality and recruitment were negatively related to the basal area stand (Breugel et al., 2006).

Based on the relationship analysis, it was revealed that the initial basal area had a significant relationship with the growth dimension of the direct proportion. The relationship described that the stand in the early stages of succession was caused by the dominant pioneer species including the recruitment. The three years of post eruption of the site is still dominated by sand and rocks. A fresh rock surface exposed by the volcanic eruption will undergo primary succession, and the site lacks of organic matters which have not been altered in any way by living organisms (Kimmins, 1997; Walker and del Moral, 2003). The low recruitment of availability and the higher species mortality were caused by the limitation of land carrying capacity. The safe site refers to the 
edaphic conditions or opportunities suitable for successful seedling recruitment (Strykstra et al., 2002). Clark et al. (1999) found that the seedling recruitment usually falls into one of two broad categories of recruitment limited by: (1) low or uncertain seed supply and establishment; or (2) lack of suitable microsites and factors that affect early seedling growth and mortality.

A major finding in this study revealed that the growth of $A$. decurrens was higher than those found in the area (not in the new surface) with a maximum of $590 \pm 119 \mathrm{~cm}$ height with a mean of annual growth rate of $87 \mathrm{~cm}$ year $^{-1}$ (Arredondo et al., 1998). The standing stock (volume $=184.44 \pm 24.59 \mathrm{~m}^{3} / \mathrm{ha}$ ) of $A$. decurrens was very potential in supporting the woodfuel stock because its stand was not only found in GMNP area, but also in the private land of Kaliadem village. In order to determine the transitional process of such areas and establish an appropriate management strategy for achieving the projected conversion, an understanding of the growth traits of these successional species was important, especially with regards to the dominant species (Miyazawa et al., 2006).

Traditionally, A. decurrens was one of the main species, serving as a potential tree for supplying woodfuel for the local community residing in GMNP. Usually, for charcoal requirement, the required minimum diameter of $A$. decurrens is about $10 \mathrm{~cm}$. Similar patterns had been found elsewhere, such as in the dry forest of Puerto Rico, whereby the species density and basal area as a succession result were recovered faster in areas used for charcoal production (Colon and Lugo, 2006). It is very important because some forest degradations have caused the intervention of the local people in looking for woodfuel. In particular, the commercial woodfuel demand for household and commercial uses is said to be contributing to the over-exploitation of forest resources (Bensel, 2008).

The existent of $A$. decurrens stand and its potential standing stock can be minimized by the intervention of the local people living in the surrounding area of GMNP, especially for woodfuel. Besides that, the results of this study had been catalyzed as the pioneer of the early stage of succession, which could serve as useful information for the lava tour in Kaliadem after the Merapi eruption in 2006. Finally, the findings are very important for future consideration because they also serve as the scheme for the policy makers and new compatible management of GMNP.

\section{References}

Arredondo, S., Aronson, J., Ovalle, C., del Pozo, A., \& Avendano, J. (1998). Screening multipurpose legume trees in central Chile. Forest Ecology and Management, 109, 221-229.

Bensel, T. (2008). Fuelwood, deforestation, and land degradation: 10 Years of evidence from Cebu Province, The Philippines. Land Degrad. Develop, 19, 587-605.

Breugel, M. v., Bongers, F., \& Martínez-Ramos, M. (2007). Species dynamics during early secondary forest succession: recruitment, mortality and species turnover. Biotropica, Volume 39 Issues 5, 610-619.

Breugel, M. v., Martínez-Ramos, M., \& Bongers, F. (2006). Community dynamics during early secondary succession in Mexican tropical rain forests. Journal of Tropical Ecology, 22, 663-674.

Charbonnier, S.J., \& Gertisser, R. (2008). Field observations and surface characteristics of pristine block-and-ash flow deposits from the 2006 eruption of Merapi Volcano, Java, Indonesia. Journal of Volcanology and Geothermal Research, 177, 971-82.

Clark, J.S., Beckage, B., Camill, P., Cleveland, B., HilleRisLambers, J., Lichter, J., McLachlan, J., Mohan, J., \& Wyckoff, P. (1999). Interpreting recruitment limitation in forests. Am. J. Bot, 86, 1-16.

Condit, R., Hubbell, S., \& Foster, R.B. (1994). Density dependence in two understory tree species in a neotropical forest. Ecology, 75, 671-680.

Colón, S.M., \& Lugo, A.E. (2006). Recovery of a Subtropical Dry Forest after abandonment of different land uses. Biotropica 38:354-364.

Dove, M.R. (2008). Perception of volcanic eruption as agent of change on Merapi volcano, Central Java. Journal of Volcanology and Geothermal Research, 172, 329-337.

Hadikusumah, H.K., Balla, M.K., Chaudhary, S., Karkee, T.B., Cruz, F.A., Ortega-Espaldon, M.V., Juma, J.C., Polthanee, A., Suphanchaimat, N., \& Na-Lampang, P. (1991). Wood fuel flows: rapid rural appraisal in four Asian countries. FAO, Bangkok, Thailand, 222 pp.

Kimmin, J.P. (1997). Forest ecology a foundation for sustainable management. Prentice Hall, Upper Saddle River, New Jersey. 
Lavigne, F., Thouret, J.C., Voight, B., Suwa, H., \& Sumaryono, A. (2000). Lahars at Merapi volcano, Central Java: an overview. Journal of Volcanology and Geothermal Research, 100, 423-456.

McDonald, T., Wale, K., \& Bear, V. (2002). Restoring blue gum high forest: lessons from Sheldon Forest. Ecological Management and Restoration VoL 3 No 1.

Ministry of Forestry, Indonesia. (2004). Ministry of Forestry Decision (SK.134/MENHUT-II/2004). Changing function forest conservation, sanctuary and natural park recreation merapi located at Magelang, Boyolali and Klaten District, Central Java Province and Sleman District, Yogyakarta Province to Gunung Merapi National Park. [Online] Available: http://www.dephut.go.id (February 3, 2010)

Miyazawa, Y., Tatsuya, S., Kikuzawa, K., \& Otsuki, K. (2006). The light environment, morphology and growth of the early successional tree species Litsea citiodora. Forest Ecology and Management, 236, 251-258.

Niklas, K. J., Midgley, J. J., \& Enquist, B. J. (2003). A general model for mass-growth-density relations across tree-dominated communities. Evolutionary Ecology Research, 5, 459-468.

Roberts, M.R. (2007). A conceptual model to characterize disturbance severity in forest harvests. Forest Ecology and Management, 242, 58-64.

Seymour, R.S., White., A.S., \& deMaynadier, P.G. (2002). Natural disturbance regimes in northeastern Nort America-evaluating silvicultureal systems using natural scales and frequencies. Forest Ecology and Management, $155,357-367$.

Strykstra, J.R., Bekker, R.M., \& Van Andel, J. (2002). Dispersal and life span spectra in plant communities: a key to safe site dynamics, species coexistence and conservation. Ecography, 25, 145-160.

Suryanto, P., Zaki, M.H., Azani, M.A., \& Azmy, M. (2010). Species diversity of Gunung Merapi National Park, Java, Indonesia following 2006 eruption. Res.Environ.Life Sci., 3 (1):1-6.

Uriarte, M., Canham, C. D., Thompson, J., \& Zimmerman, J. K. (2004). A neighborhood analysis of tree growth and survival in a Hurricane-Driven Tropical Forest. Ecological Monographs, 74, 591-614.

Walker, L.R., \& del Moral, R. (2003). Primary Succession and Ecosystem Rehabilitation. Cambridge: Cambridge University Press.

Table 1. The dynamics growth of A.decurrens

\begin{tabular}{|c|c|c|c|c|c|c|}
\hline \multirow{2}{*}{ Plot } & \multicolumn{2}{|c|}{ Diameter (cm) } & \multicolumn{2}{c|}{ Height (m) } & \multicolumn{2}{c|}{ Density (individuals/ha) } \\
\cline { 2 - 7 } & 2008 & 2009 & 2008 & 2009 & 2008 & 2009 \\
\hline P1 & $4.07 \pm 1.86$ & $6.22 \pm 1.93$ & $2.92 \pm 1.20$ & $4.12 \pm 1.77$ & $21078.26 \pm 5058.78$ & $23965.22 \pm 4553.39$ \\
\hline P2 & $3.90 \pm 1.82$ & $4.85 \pm 0.63$ & $2.39 \pm 0.50$ & $3.03 \pm 0.56$ & $243.48 \pm 51.17$ & $330.44 \pm 69.31$ \\
\hline P3 & $6.61 \pm 1.26$ & $9.18 \pm 1.29$ & $3.95 \pm 0.55$ & $5.38 \pm 0.54$ & $4069.57 \pm 1017.39$ & $4486.96 \pm 1076.86$ \\
\hline P4 & $8.64 \pm 0.95$ & $14.22 \pm 1.85$ & $3.42 \pm 0.55$ & $5.97 \pm 0.66$ & $2834.78 \pm 510.26$ & $3234.78 \pm 517.59$ \\
\hline
\end{tabular}


Table 2. Relative rate change of A.decurrens on three years after Merapi eruption

\begin{tabular}{|c|c|c|c|c|c|c|c|c|}
\hline \multirow{2}{*}{ Plot } & \multicolumn{8}{|c|}{ RRC (\%) } \\
\hline & Diameter & Height & Density & Basal Area & Volume & Recruitment & Mortality & Survival \\
\hline $\mathrm{P} 1$ & $88.78 \pm 15.98$ & $67.04 \pm 28.22$ & $21.23 \pm 4.57$ & $235.36 \pm 64.02$ & $337.71 \pm 90.86$ & $3338.06 \pm 500.71$ & $11566.73 \pm 1850.67$ & $50671.10 \pm 6587.24$ \\
\hline $\mathrm{P} 2$ & $38.60 \pm 6.56$ & $42.45 \pm 8.49$ & $58.10 \pm 12.20$ & $72.97 \pm 14.11$ & $185.44 \pm 35.82$ & $513.15 \pm 56.45$ & $449.72 \pm 80.95$ & $2866.58 \pm 401.32$ \\
\hline P3 & $63.58 \pm 10.49$ & $58.75 \pm 7.08$ & $15.77 \pm 3.86$ & $127.61 \pm 22.56$ & $217.63 \pm 38.44$ & $369.78 \pm 66.56$ & $794.13 \pm 103.24$ & $3046.12 \pm 668.59$ \\
\hline P4 & $111.05 \pm 13.33$ & $131.89 \pm 17.80$ & $21.90 \pm 3.72$ & $248.41 \pm 35.19$ & $596.80 \pm 83.52$ & $334.19 \pm 56.81$ & $455.01 \pm 59.15$ & $2747.12 \pm 302.18$ \\
\hline
\end{tabular}

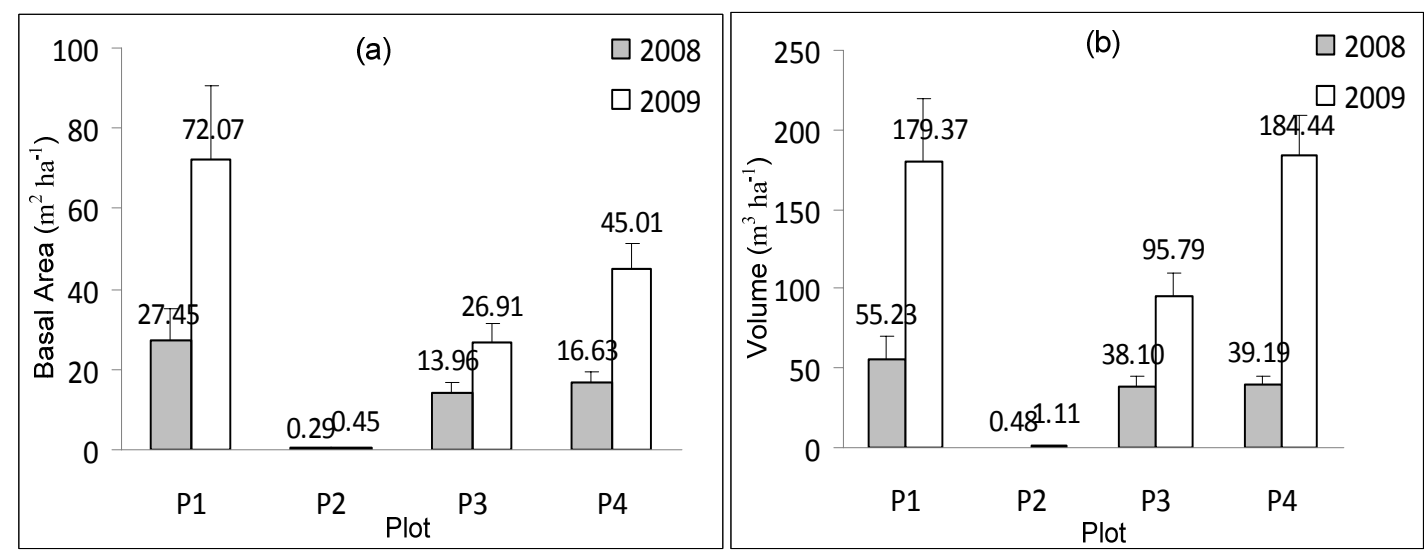

Figure 1. Standing stock of A.decurrens with basal area (a) and volume (b)

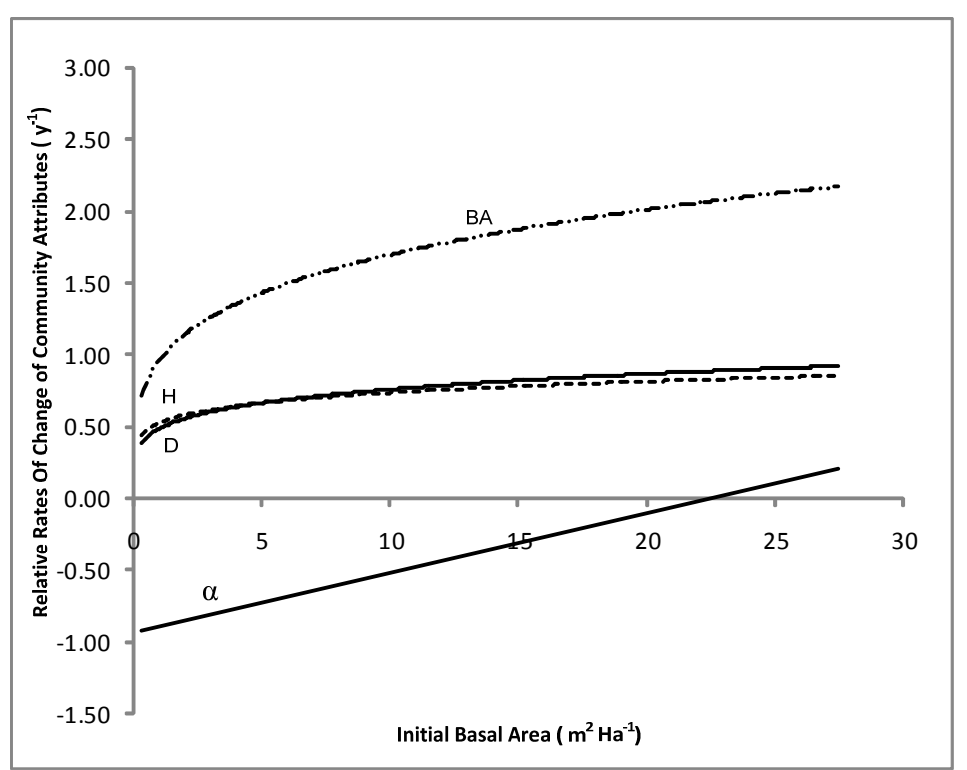

Figure 2. Trend initial basal area and relative rates of changes basal area, diameter and height 